\title{
Age at Menarche and Related Factors in Girls of Urban Areas of Markazi (Central) Province of Iran
}

\author{
Edad de la Menarquia y Factores Relacionados en las \\ Niñas de Zonas Urbanas de la Provincia Markazi (Central) de Irán \\ "ParvinDokht Bayat; "**Ali Ghanbari; "*Mozafar Khazaei; "*Rostam Ghorbani \& *"Sara Amiri
}

BAYAT, P.; GHANBARI, A.; KHAZAEI, M.; GHORBANI, R. \& AMIRI, S. Age at menarche and related factors in girls of urban areas of Markazi (Central) Province of Iran. Int. J. Morphol., 30(1):15-18, 2012.

SUMMARY: The age at menarche is an indicator of racial, geographical and nutritional patterns of different societies. This cross-sectional study conducted on 1223 girls aged 14-20 in the Markazi (Central) Province, Iran in 2010. In this research, the age at menarche, as the main variable, was determined for each city and compared between different cities. The statistical analyses included c2 test for determining statistically significant differences, variance analysis for determining the difference between groups, and Pearson correlation coefficient for determining the relationship between variables. The average age of first menstruation was $13.21 \pm 1.33$ years in the Markazi Province, with no significant difference among the cities of the province. This age is inversely related to body mass index (BMI), nutritional status and weight. The pattern of distribution of BMI is similar for all the cities in the province. Although, the average age at menarche in the Markazi (central) Province, a cold area, is higher compared to warmer regions in Iran, it may be more influenced by race than by the climate. Considering the lower age at menarche in Markazi Province compared to previous similar studies, it may be stated that social well-being and nutritional standards have improved in the province.

KEY WORDS: Fertility; Growth; Iran; Menarche.

\section{INTRODUCTION}

Menstruation is considered a sign of sexual health during the adolescence and fertility age of women. Historically, it has been celebrated as the gift of puberty in many human societies. Puberty is the result of hormonal changes in the hypothalamus-pituitary-gonad axis. This axis is stimulated weakly by placental hormones in the female fetus and it leads to secretion of gonadotropin releasing hormone $(\mathrm{GnRH})$ in the neonatal period. This hormone decreases and remains minimal up to adolescence when the occurrence of first menstruation marks it rapid increase (Grumbach, 2002; Speroff et al., 1999).

Researchers have reported genetic factor as the most influential factor on the time of first menses (Chumlea $e t$ al., 2003). Other factors including altitude of residence (Uche-Nwachi et al., 2007) nutritional pattern, body mass index, size of newborn at birth (Tanner \& Davies, 1985), mental, economic and social factors (Towne et al., 2005; Wyshal \& Frisch, 1982) have been indicated, as well.
The age at menarche (first menstruation) is clinically valuable, since it forms a basis for diagnosing delayed puberty and pathologic and hormonal disorders. The age of first menstruation is different among various ethnicities. In the United States, the average age at menarche has shifted from 12.75 to 12.54 years over a period of 25 years. The age at menarche is reportedly 12.9 years in Europe, $12.5-12.9$ in different regions of India, and 13.3 years in Africa (Anderson et al., 2003; Bektas, 2008; Ogata, 1979; Wyshal \& Frisch). It appears that the level of development of a society is inversely related to the age of first menstruation which is higher in underdeveloped regions. An example is illustrated by girls from the very poor Bundi region of New Guinea whose average age of first menstruation is 18.8 years, comparable to Europeans of one century ago (Cagas \& Riley, 1970).

Some studies have been conducted in Iran about the age of first menstruation; however, considering the fact that

\footnotetext{
* Department of Anatomy, Arak University of Medical Sciences, Arak, Iran.

** Fertility and Infertility Research Center, Kermanshah University of Medical Sciences, Kermanshah, Iran.

**** Student Research Committee, Kermanshah University of Medical Sciences, Kermanshah, Iran.
} 
this variable changes with changes in the society and also the fact that age at menarche is an indicator of growth health of people in a society. The aim of present work was to evaluate the factors influencing the age at menarche in Markazi (Central) Province of Iran and to compare the data to those of other studies in Iran and worldwide.

\section{MATERIAL AND METHOD}

This cross-sectional study carried out on 1223 girls aged 14-20 years who were students of national high schools in Markazi (Central) Province, Iran in 2010. Considering the objectives of the study, we used age at menarche, the main variable, as the basis for calculating the sample volume. Using a confidence coefficient of $95 \%$ and accuracy of 0.5 , the sample volume was calculated to be 1200 people. Cluster sampling was performed in each city based on the number of girls of the desired age range. A questionnaire was designed and verified for validity and reliability by researchers. A briefing class was held for people in charge of distributing the questionnaires to ensure homogeneity. The questionnaires were submitted to the people in study. Those girls with hormonal disorders, anemia and chronic infections such as tuberculosis and major thalassemia were excluded from the study.

The questionnaire contained questions about the following issues: date of birth, age of first menstruation, city of residence, paternal/maternal education, size of family, economical status, weight, height. Based on the amount of meat and dairy products consumed daily, the economic status was evaluated as Good, Average, and Poor.
The body mass index was calculated using the equation BMI= Weight (kg)/Height2 (m2) (4). The samples were divided into 5 categories: below $15 ; 15.1-20 ; 20.1-25$, 25.1-30; and above 30. The collected data were analyzed using compare means. The $\mathrm{c} 2$ test was used for determining statistically significant differences, and analysis of variance was used for determining the difference between groups. The Pearson correlation coefficient was used to determine the relationship between variables.

\section{RESULTS}

Table I shows the data of age of the girls and families. The mean age of the girls was $16.07 \pm 0.98$ years $(14-20$ years). $31.8 \%$ were aged $14-14.9$, and $50.8 \%$ were aged 15 15.9 years. The mean size of families was $4.85 \pm 1.23$ people (2-11 people), with $37.6 \%$ and $33 \%$ of cases living in families of 4 and 5 people, respectively.

The mean age at menarche was $13.21 \pm 1.16$ years. Table II illustrates this variable for different cities of the province. The relationship between age at menarche with anthropometric dimensions (Weight, Height and BMI), economic condition, season of first menstruation, number of family members, cities is summarized in Table III. Age at menarche is influenced by Weight and BMI. Although age at menarche is not related to the economic condition and the number of family members, it influenced by the cities. This data is derived because the cities influence on economy and the later correlate with the number of family members by itself. The data also showed that age at menarche in Markazi Province of Iran is not related to the season (Table III).

Table I. The age of the girls and family member's number in sampled urban population of the girls in markazi (Central) province of Iran in 2010.

\begin{tabular}{lcccc}
\hline Mean & SD & Minimum & Maximum & Mean \\
\hline Age & 16.07 & 0.98 & 14 & 20 \\
Family member's number & 4.8515 & 1.23188 & 2 & 11 \\
\hline
\end{tabular}

Table II. Average age at menarche in sampled urban population of the girls in Markazi (central) Province of Iran in 2010 (2.2\% Excluded).

\begin{tabular}{lccc}
\hline City & Mean & n & SD \\
\hline Arak & 13.2038 & 417 & 1.17022 \\
Shazand & 13.3867 & 150 & 1.13242 \\
Saveh & 13.3010 & 98 & 1.23676 \\
Khomien & 13.2661 & 124 & 1.06770 \\
Mahalat & 13.1986 & 146 & 1.18391 \\
Delijan & 13.5205 & 122 & 1.21356 \\
Farahan & 12.7432 & 148 & .99742 \\
\hline
\end{tabular}


BAYAT, P.; GHANBARI, A.; KHAZAEI, M.; GHORBANI, R. \& AMIRI, S. Age at menarche and related factors in girls of urban areas of Markazi (Central) Province of Iran. Int. J. Morphol., 30(I):15-18, 2012

Table III. Correlation between average age at menarche in sampled urban population of the girls and other factors in Markazi (central) Province of Iran in 2010

\begin{tabular}{lllllll}
\hline & \multicolumn{1}{c}{$\begin{array}{c}\text { Geographic area } \\
\text { (Cities) }\end{array}$} & $\begin{array}{c}\text { Economic } \\
\text { condition }\end{array}$ & Season & weight & $\begin{array}{c}\text { Family } \\
\text { number }\end{array}$ & BMI \\
\hline $\begin{array}{l}\text { A verage age at } \\
\text { menarche }\end{array}$ & $-.059 *$ & $-.079^{*}$ & 0.46 & $-.197^{* *}$ & -0.130 & $\mathbf{0 . 1 4 3 * *}$ \\
\hline p-Value & $\mathbf{0 . 0 4 0}$ & $\mathbf{0 . 0 1 6}$ & $\mathbf{0 . 0 8 0}$ & $\mathbf{0 . 0 0 0}$ & $\mathbf{0 . 0 7 6}$ & $\mathbf{0 . 0 0}$ \\
\hline
\end{tabular}

${ }^{*}$ Correlation is significant at the 0.05 level ( 2 tailed) ${ }^{* *}$ Correlation is significant at the 0.01 level ( 2 tailed)

\section{DISCUSSION}

The study showed that the average age at menarche differed among the cities of Markazi Province of Iran. This data is in parallel to the study conducted in Spain that show that the age of first menstruation is lower in large cities compared to small cities (Cabanes et al., 2009) and the one in Mazandaran Province of Iran that confirms that the age at menarche in urban areas is lower than the rural (Delavar \& Hajian-Tilaki, 2008).

The present study showed that the age at menarche in urban girls in Markazi province of Iran is not related to the season. It seems that, winter as harvest season for improving nutritional status in rural population that previously observed in Bangladesh is not affecting urban girls of our study (Rah $e t$ al., 2009). In other words, the pattern of consumption of food is steady during the year in urban population of Markazi Province which is in contrast with both rural and urban population in Mazandaran Province of Iran (Delavar \& Hajian-Tilaki).

The age at menarche in our province was lower compared to underdeveloped countries (mostly in Africa) such as Algeria (14.3 years), Haiti (13.98 years), Bangladesh (15.8\%), Ghana (13.83 years), Tanzania (14 years), Congo (15.21 years), Nigeria (15.37 years), Yemen (14.4 years), and Senegal (16.1 years). On the other hand, the average age at menarche in Markazi Province was higher compared to more developed countries such as Greece (12 years), the United States (12.8 years), and Italy (12.2 years) (Thomas et al., 2001).

However, reports from other regions of the world, such as Germany (14 years), Czech Republic (14.6 years) and Congo-Brazzaville (12 years) convinces us that the age at menarche cannot be accounted for solely by level of development (Thomas et al., 2001). Many researchers have noticed race and environmental factors, such as climate of residence, to have influenced the age at menarche (Tanner \& Davies; Towne et al.; Uche-Nwachi et al.; Wyshal, \& Frisch). Thus, it can be stated that the pattern of age at menarche may be influenced by ethnical sub-groups; in the black race, for instance, the age at menarche is higher in Tanzania, Ghana, Congo and Nigeria compared to Congo-Brazzaville. As for Caucasians, Germany and Czech Republic have higher ages of menarche compared to Italy and Greece. In the case of United States, however, the ethnic diversity prevents us from attributing the age at menarche to any single race.

An important hypothesis concerning the age at menarche is Frisch's theory which states that menstruation occurs when body attains the critical mass of 48 kilograms or when body fat increases from $16 \%$ to $23 \%$ (Speroff et al.). The findings of our study corroborate this theory: weight and body mass index are inversely related to age at menarche and the higher they are, the lower the age at menarche will be.

In Iran's case, studies indicate that there are differences in anthropometric indices, such as cephalometric indices, in different subgroups (Bayat \& Ghanbari, 2009, 2010); however, the significance of these differences in age at menarche can be considered as an area of future research. This statement is based on a study that mentions that the pattern of menarche in cold Azeri regions of northwestern Iran is consistent with southern, eastern and some central regions of Iran which have warm climate (Mohammad et al., 2006). In other words, although the climate to be influential on the age at menarche and mountainous, cold climates have higher ages of menarche, the ethnicity has more effective that can be seen in Azari racial subgroup of Iranian population.

In the Markazi (Central) Province of Iran, the age at menarche has been shifted down from 13.90 to 13.69 years over a decade from 1990 to 2000 . The present study is conducted almost 30 years after the last similar study (Mohammad et al.). Comparing our findings to those of the last similar study indicates that the average age at menarche has decreased by 0.48 years in Markazi Province over the last 30 years. Lowere age at menarche is an indicator of improved nutritional status, as researches in other countries confirm the lowering of age at menarche in the last century.

In conclusion, the pattern of age at menarche and the pattern of distribution of body mass index are similar in cities of Markazi (Central) Province of Iran which may be accounted for by similarities in climate, ethnic and nutritional patterns. The age at menarche in Markazi Province is shifting down, consistent with developed countries during last decades. 
BAYAT, P.; GHANBARI, A.; KHAZAEI, M.; GHORBANI, R. \& AMIRI, S. Edad de la menarquia y factores relacionados en las niñas de zonas urbanas de la Provincia Markazi (Central) de Irán. Int. J. Morphol., 30(1):15-18, 2012.

RESUMEN: La edad de la menarquia es un indicador de patrones raciales, geográficos y nutricionales de distintas sociedades. Este estudio transversal fue realizado el 2010 en 1223 niñas entre 14 y 20 años en la Provincia Markazi (Central), Irán. En esta investigación, la edad de la menarquia, como la variable principal, se determinaron para cada ciudad y en comparación entre las diferentes ciudades. Los análisis estadísticos incluyeron la prueba $\mathrm{c}^{2}$ para determinar diferencias estadísticamente significativas, el análisis de varianza para determinar la diferencia entre los grupos, y el coeficiente de correlación de Pearson para determinar la relación entre las variables. El promedio de edad de la primera menstruación fue 13,21 $\pm 1,33$ años en la provincia de Markazi, sin diferencias significativas entre las ciudades de la provincia. Esta edad es inversamente proporcional al índice de masa corporal (IMC), el estado nutricional y el peso. El patrón de distribución del IMC es similar para todas las ciudades de la provincia. Aunque la edad media de la menarquia en la Provincia Markazi (central), una zona de clima frío, es mayor en comparación con las regiones más cálidas en Irán, puede estar más influenciadas por la raza que por el clima. Teniendo en cuenta la baja edad de menarquia en la Provincia Markazi en comparación con estudios similares anteriores, se puede afirmar que el bienestar social y los niveles de nutrición han mejorado en la provincia.

PALABRAS CLAVE: Fertilidad; Crecimiento; Irán; Menarquia.

\section{REFERENCES}

Anderson, S. E.; Dallal, G. E. \& Must, A. Relative weight and race influence average age at menarche: results from two nationally representative surveys of US girls studied 25 years apart. Pediatrics, 111(4 Pt 1):844-50, 2003.

Bayat, P. D. \& Ghanbari, A. The evaluation of craniofacial dimensions in female Arak newborns (central Iran) in comparison with other Iranian racial subgroups. Eur. J. Anat., 13(2):77-82, 2009.

Bayat, P. D. \& Ghanbari, A. Comparison of the Cranial Capacity and Brain Weight of Arak (Central Iran) with other Subgroups of Iranian Population. Int. J. Morphol., 28(1):323-6, 2010.

Bektas, Y. Age at menarche in Ankara, Turkey. Anthropologiai Közlemények, 49:51-9, 2008.

Cabanes, A.; Ascunce, N.; Vidal, E.; Ederra, M.; Barcos, A.; Erdozain, N.; Lope, V. \& Pollán, M. Decline in age at menarche among Spanish women born from 1925 to 1962. BMC Public Health, 9:449, 2009

Cagas, C. R. \& Riley, H. D. Jr. Age of Menarche in Girls in a WestSouth-Central Community. Am. J. Dis. Child., 120(4):303-8, 1970.

Chumlea, W. C.; Schubert, C. M.; Roche, A. F.; Kulin, H. E.; Lee, P. A.; Himes, J. H. \& Sun, S. S. Age at menarche and racial comparisons in US girls. Pediatrics, 111(1):110-3, 2003.

Delavar, M. A. \& Hajian-Tilaki, K. O. Age at menarche in girls born from 1985 to 1989 in Mazandaran, Islamic Republic of Iran. East. Mediterr. Health. J., 14(1):90-4, 2008.

Grumbach, M. M. The neuroendocrinology of human puberty revisited. Horm. Res., 57(Suppl 2):2-14, 2002.

Mohammad, K.; Zeraati, H.; Majdzadeh, R. \& karimloo, M. Evaluating the trend of change in the mean onset age of menarche in Iranian girls. J. Reprod. Infertil., 6(5):523-30, 2006. ..EN TEXO Kazem, M.
Ogata, A. Age at menarche and marriage in Bangladesh women. $J$. Trop. Med. Hyg., 82(4):68-74, 1979.

Rah, J. H.; Shamim, A. A.; Arju, U. T.; Labrique, A. B.; Rashid, M. \& Christian, P. Age of onset, nutritional determinants, and seasonal variations in menarche in rural Bangladesh. J. Health Popul. Nutr., 27(6):802-7, 2009.

Speroff, L.; Glass, R. H. \& Kase, N. G. Clinical Gynecologic Endocrinology and Infertility. $6^{\text {th }}$ Ed. Philadelphia, Lippincott Williams \& Wilkins, 1999.

Tanner, J. M. \& Davies, P. S. Clinical longitudinal standards for height and height velocity for North American children. J. Pediatr., 107(3): 317-29, 1985

Thomas, F.; Renaud, F.; Benefice, E.; de Meeüs, T. \& Guegan, J. F. International variability of ages at and menopause: Patterns and main determinants Menarche. Hum. Biol., 73(2):271-90, 2001.

Towne, B.; Czerwinski, S. A.; Demerath, E. W.; Blangero, J.; Roche, A. F. \& Siervogel, R. M. Heritability of age at menarche in girls from the Fels Longitudinal Study. Am. J. Phys. Anthropol., 128(1):210-9, 2005

Uche-Nwachi, E. O.; Odekunle, A.; Gray, J.; Bethel, T.; Burrows, Y.; Carter, J.; Christie, K.; Dillett, J.; Evelyn, C.; Stubbs, L. Osolo, I. \& workman, T. Mean age at menarche in Trinidad and its relationship to body mass index, ethnicity and mothers age at menarche. Online. J. Biol. Sci., 7(2):66-71, 2007.

Wyshak, G. \& Frisch, R. E. Evidence for a secular trend in age at menarche. N. Engl. J. Med., 306(17):1033-5, 1982.

Correspondence to:

Ali Ghanbari

Fertility and Infertility Research Center

Kermanshah University of Medical Sciences

P.O. Box 1568, Kermanshah

IRAN

Email: aghanbari@kums.ac.ir

Received: 03-06-2011

Accepted: 17-08-2011 